\title{
PEMANFAATAN EKSTRAK DAUN CENGKEH (Syzygium aromaticum L.) SEBAGAI HERBISIDA ALAMI TERHADAP PERTUMBUHAN GULMA RUMPUT TEKI (CYPERUS ROTUNDUS L.)
}

\author{
Diana R. Talahatu ${ }^{1}$, Pamela Mercy Papilaya ${ }^{2}$ \\ ${ }^{1}$ Alumni Program Studi Pendidikan Biologi \\ ${ }^{2}$ Staf Pengajar Program Studi Pendidikan Biologi
}

E-mail: diana_talahatu@yahoo.com

\begin{abstract}
Background: Clove is a spice native plants Maluku Islands, and has been traded and cultivated for generations in the form of people's plantation. Separation of chemical constituents of clove showed that clove leaves contain saponins, alkaloids, flavonoid glycosides and tannins. Flavonoids are one of the types of compounds that are toxic / residues, the sugar bound compound from the flavonoids. Flavonoids have distinctive properties that is a very sharp odor, bitter taste, soluble in water and organic solvents, and easily decompose at high temperatures.

Methods: This study was conducted in February-April of 2015 at the Laboratory and Greenhouse biology education Pattimura University. This research is a lab experiment. Clove leaf extract obtained by polar solvent is macerated with ethanol $96 \%$ and then applied to the growth of weeds sedges. Clove leaf extract concentration used a $5 \%, 10 \%, 20 \%, 50 \%$ and control.

Results: There is a natural herbicide effectiveness of clove leaf extract at a concentration of $50 \%$, which can be used as an alternative to inhibit the growth of tall weeds sedges.

Conclusion: The higher the clove leaf extract given against weeds sedges will increasingly serve to inhibit weed sedges as measured by plant height, phytotoxicity, fresh weight and dry weight of weeds sedges.
\end{abstract}

Keywords: Natural Herbicides, Clove Leaf Extract (Zysygium aromaticum L.), Growth, Weeds Sedges (Cyperus rotundus L.).

\begin{abstract}
Abstrak
Latar Belakang: Cengkeh merupakan tanaman rempah asli Kepulauan Maluku, dan telah di perdagangkan serta dibudidayakan secara turun-temurun dalam bentuk perkebunan rakyat. Pemisahan kandungan kimia dari daun cengkeh menunjukkan bahwa daun cengkeh mengandung saponin, alkaloid, glikosida flavonoid dan tannin. Flavonoid adalah salah satu jenis senyawa yang bersifat racun/alelopati, merupakan persenyawaan Dari gula yang terikat dengan flavon. Flavonoid mempunyai sifat khas yaitu bau yang sangat tajam, rasanya pahit, dapat larut dalam air dan pelarut organik, serta mudah terurai pada temperatur tinggi.

Metode: Penelitian ini dilakukan dari bulan Februari - April 2015 pada Laboratorium dan Greenhouse pendidikan biologi Universitas Pattimura. Penelitian ini merupakan penelitian eksperimen laboratorium. Ekstrak daun cengkeh didapat dengan cara dimaserasi dengan pelarut polar yaitu ethanol $96 \%$ kemudian di aplikasikan terhadap pertumbuhan gulma rumput teki. Konsentrasi ekstrak daun cengkeh yang digunakan $5 \%, 10 \%, 20 \%, 50 \%$ dan kontrol.

Hasil: Terdapat efektifitas herbisida alami ekstrak daun cengkeh pada konsentrasi $50 \%$ yang dapat gunakan sebagai salah satu alternatif untuk menghambat pertumbuhan tinggi gulma rumput teki.

Kesimpulan: Semakin tinggi ekstrak daun cengkeh yang diberikan terhadap gulma rumput teki maka akan semakin berpotensi menghambat gulma rumput teki yang diukur dari tinggi tanaman, fitotoksisitas, berat basah dan berat kering gulma rumput teki.
\end{abstract}

Kata Kunci: herbisida alami, ekstrak daun cengkeh (Zysygium aromaticum L.), pertumbuhan, gulma rumput teki (Cyperus rotundus L.). 


\section{PENDAHULUAN}

Gulma merupakan tumbuhan yang tumbuh pada waktu, tempat dan kondisi yang tidak diinginkan manusia. Menurut Junaedi Ahmad, dkk (2006) gulma merupakan tumbuhan yang tumbuh di tempat yang tidak dikehendaki terutama di tempat manusia bermaksud mengusahakan tanaman budidaya. Keberadaan gulma pada areal tanaman budidaya dapat menimbulkan kerugian baik dari segi kuantitas maupun kualitas produksi. Kerugian yang ditimbulkan oleh gulma adalah penurunan hasil pertanian akibat persaingan dalam perolehan air, unsur hara, tempat hidup, penurunan kualitas hasil, menjadi inang hama dan penyakit, membuat tanaman keracunan akibat senyawa racun atau alelopati.

Gulma bersaing untuk hidup dengan lingkungannnya baik diatas maupun dibawah tanah. Adanya gulma tersebut membahayakan bagi kelangsungan pertumbuhan dan menghalangi tercapainya sasaran produksi pertanaman pada umumnya. Usaha manusia dalam mengatasi hal tersebut dapat berupa pemberantasan atau pengendalian, tergantung pada keadaan tanaman, tujuan bertanam dan biaya.

Dalam mengendalikan gulma diperlukan cara yang tepat untuk memberantas gulma-gulma yang tumbuh di daerah pertanaman. Ada berbagai cara yang dapat di lakukan dalam mengendalikan gulma, salah satunya pengendalian gulma secara kimiawi, ialah pengendalian gulma dengan menggunakan bahan kimiawi yang dapat menekan atau bahkan mematikan gulma. Bahan kimiawi itu disebut herbisida (herba = gulma dan sida $=$ membunuh) berarti zat herbisida ialah zat kimiawi yang dapat mematikan gulma. Herbisida dapat masuk ke dalam jaringan tumbuhan selain melalui penyerapan oleh akar tanaman, juga dapat melalui penetrasi stomata (Fatonah S, dkk, 2013). Pengendalian dengan cara ini membutuhkan alat penyebar herbisida serta pengetahuan tentang herbisida itu sendiri, agar pengendalian yang dilakukan dapat berhasil.

Untuk membersihkan lahan dari rumput/gulma biasanya dilakukan beberapa kali, kalau rumput tebal biasanya petani membakarnya kemudian dibiarkan sekitar dua minggu sampai rumput mulai tumbuh lagi, setelah itu disemprot dengan herbisida yang relatif sangat banyak dan sering, hal inilah yang menyebabkan pembengkakan biaya usaha para petani. Akhirnya banyak usaha dilakukan petani untuk menghemat pengeluaran belanja herbisida dengan cara mereka sendiri, dengan membuat herbisida yang ramah lingkungan dengan biaya yang sedikit tetapi dapat bermanfaat untuk meningkatkan hasil uasaha para petani (Anonim, 2012).

Dalam rangka mendukung gerakan pertanian organik di Indonesia, diperlukan herbisida organik yang efektif berskala komersial. Salah satu yang dapat digunakan sebagai herbisida alami yaitu daun cengkeh, daun cengkeh belum termanfaatkan secara maksimal dan masih dianggap limbah yang kurang berguna. Padahal daun cengkeh memiliki kandungan minyak atsiri 1 - 4\%, yang dapat dimanfaatkan sehingga limbah tersebut memiliki nilai ekonomis yang tinggi. walaupun belum ada yang meneliti mengenai hal ini, maka dalam penelitian ini akan diteliti ekstrak dari daun cengkeh sebagai herbisida alami, dari daun cengkeh yang hanya dibiarkan menjadi sampah dapat dipakai guna untuk membantu memudahkan para petani untuk mendapatkan herbisida yang murah, mudah dijangkau dan ramah linngkungan (Riadi, $d k k, 2012$ ).

Cengkeh merupakan tanaman rempah asli Maluku Utara/Kepulauan Maluku (Bustaman Sjahrul, 2011) dan telah di perdagangkan serta dibudidayakan secara turun-temurun dalam bentuk perkebunan rakyat. Pemisahan kandungan kimia dari daun cengkeh menunjukkan bahwa daun cengkeh mengandung saponin, alkaloid, glikosida flavonoid dan tannin. Flavonoid adalah salah satu jenis senyawa yang bersifat racun/alelopati, merupakan persenyawaan Dari gula yang terikat dengan flavon (Fatonah Siti, $d k k, 2013$ ). Flavonoid mempunyai sifat khas yaitu bau yang sangat tajam, rasanya pahit, dapat larut dalam air dan pelarut organik, serta mudah terurai pada temperatur tinggi (Faqihhudin, dkk, 2014).

Flavonoid tersebar luas pada tumbuhan, flavonoid terdapat pada semua 
bagian tumbuhan termasuk daun, akar, kayu, kulit, tepung sari, nektar, bunga, buah dan biji yang juga mengandung senyawa alelopati (Ellizar dan Maaruf Y, 2009). Senyawa alelopati merupakan senyawa yang bersifat toksik yang dihasilkan oleh suatu tanaman. Senyawa alelopati dari tumbuhan atau mikro organisme yang berpengaruh sebagai herbisida sangat memberikan insentif bagi kesehatan dan kelestarian lingkungan (Faqihhudin, dkk, 2014). Menurut Faqihhudin, dkk (2014) mengisolasi senyawa ailantona dari kulit akar pohon Ailanthus altissima yang berpengaruh sebagai herbisida pra dan pasca-tumbuh.

Penelitian yang dilakukan oleh Rahmi Fitri (2013) telah membuktikan bahwa kandungan senyawa seperti flavonoid, terpenoid, steroid, kuinon, tannin, dan saponin yang dihasilkan dari ekstrak daun ketapang dapat digunakan sebagai Bioherbisida/herbisida alami terhadap gulma rumput teki dengan konsentrasi $0 \%$, $25 \%, 50 \%, 75 \%$, $100 \%$, dari konsentrasi yang dipakai konsentrasi $50 \%$ yang lebih optimal dalam menghambat gulma rumput teki juga kandungan senyawa seperti fenol, asam fenolik, koumarin, dan flavonoid dari ekstrak tajuk sembung rambat dan ekstrak daun tembeleken dapat memberi efek fitotoksisitas dan berat basah pada rumput teki (cyperus rotundus L.) (Rahmi Fitri, 2013).

Penelitian ini bertujuan Untuk mengetahui daya hambat dari ekstrak daun cengkeh terhadap gulma rumput teki (Cyperus Rotundus L.) dan untuk mengetahui pada konsentrasi berapakah ekstrak daun cengkeh dapat menghambat gulma rumput teki (Cyperus Rotundus L.).

\section{MATERI DAN METODE}

Penelitian ini dilaksanakan pada bulan Februari sampai April 2015 di Laboratorium dan Greenhouse Biologi Dasar, Program Studi Pendidikan Biologi, Fakultas Matematika dan IImu Pengetahuan Alam Universitas Pattimura, Ambon. Bahan yang digunakan dalam Penelitian ini adalah umbi Teki (Cyperus rotundus L.) yang digunakan sebagai tanaman yang diuji. Dan daun Cengkeh (Zysygium aromaticum L.) digunakan sebagai ekstrak berpotensi herbisida alami. Selain itu juga aquades yang digunakan sebagai kontrol, etanol $96 \%$ sebagai Pelarut serta tanah sebagai media.

Alat yang digunakan adalah blender, labu Erlenmeyer, pipet, gelas ukur, timbangan analitik, Penggaris, oven, kertas saring, polibag, pisau, alumunium foil, corong Buchner bak tanam, kertas label, alat tulis.

\section{Persiapan Media Tanam}

Media tanam yang digunakan pada uji ini adalah tanah. Tanah ini terbagi menjadi dua peletakan yaitu yang pertama pada bak tanam dan yang kedua adalah pada polybag berukuran $5 \mathrm{~kg}$.

\section{Persiapan Penyemaian}

Tanah yang sudah disiapkan, dimasukkan ke dalam bak tanam dan setelah itu digunakan sebagai media semai umbi rumput teki. Umbi rumput yang akan disemai sebanyak 60 umbi. Pada bak semai tersebut dilakukan penyiraman dengan aquades secukupnya, hingga umur 15 hari.

\section{Pembuatan Ekstrak Herbisida Nabati}

Pertama-pertama Menyiapkan daun cengkeh (Syzygium aromaticum L.) yang digunakan sebagai ekstrak herbisida nabati, dimana daun cengkeh (Syzygium aromaticum L.) diperoleh di wilayah desa Rutong kecamatan Leitimur Selatan. Daun yang diambil yaitu daun cengkeh yang sudah tua (hijau pekat) daun diambil sebanyak 1000 gram, kemudian dicuci hingga bersih dan keringkan di oven dengan suhu $50^{\circ} \mathrm{C}$, selama 1 jam. Daun yang sudah kering kemudian dipotong kecil-kecil dan dihancurkan hingga halus dengan menggunakan blender. Selanjutnya serbuk ditimbang sebanyak 500 gram lalu diekstrak menggunakan metode maserasi dengan pelarut polar, yaitu etanol $96 \%$ sebanyak $700 \mathrm{ml}$ pada elyenmeyer $1000 \mathrm{ml}$ hingga serbuk benar-benar terendam seluruhnya. Perendaman dilakukan pada suhu kamar hingga 24 jam. Setelah 24 jam, hasil maserasi disaring dengan corong Buchner yang dialasi kertas saring. Selanjutnya hasil ekstraksi diuapkan pada evaporator sampai dihasilkan ekstrak murni daun cengkeh (Syzygium aromaticum L.) Ekstrak tersebut 
disimpan di lemari es sampai saat digunakan untuk pengujian. Pembuatan konsentrasi herbisida nabati terdiri atas $50 \%, 20 \%$, $10 \%$ dan $5 \%$ serta adanya kontrol dengan menggunakan aquades.

\section{Uji Pertumbuhan}

Umbi rumput teki yang sudah disemaikan selama 15 hari kemudian dipindahkan dari bak persemaian kedalam 20 buah polybag ukuran $5 \mathrm{~kg}$. Pemindahan dilakukan pada sore hari atau pagi hari sekali. Masing-masing polybag berisi 3 semaian umbi teki. Setelah itu penyiraman dengan menggunakan ekstrak daun cengkeh berbagai konsentrasi dilakukan pada saat hari kedua setelah pemindahan dari bak semaian atau pada hari ke 17 . Penyiraman ekstrak daun cengkeh dilakukan setiap 2 hari sekali hingga hari ke 30. Setiap penyiraman menggunakan pipet tetes sebanyak 10 tetes tiap tanaman.

\section{Parameter Pertumbuhan yang Diukur}

Perubahan yang diamati dari penelitian ini adalah berat basah, berat kering serta fitotoksisitas (keracunan) pada gulma rumput.

\section{Tinggi Tanaman}

Tinggi rumput teki diukur dengan menggunakan penggaris mulai panggal batang hingga ujung daun tertinggi. Pengukuran dilakukan setiap 5 hari sekali setelah pemindahan dari bak persemaian kedalam polybag.

\section{Berat Basah dan Berat Kering Berat Basah}

Berat basah rumput teki yang telah diberi perlakuan, ditimbang dengan menggunakan timbangan analitik. Pengukuran berat basah dilakukan pada hari ke-30 setelah tanaman.

\section{Berat Kering}

Berat kering rumput diperoleh dengan cara memasukan rumput dalam amplop tertutup kemudian dioven pada suhu $105^{\circ}$ selama 1 hari. Pengukuran berat kering dilakukan pada hari ke-30 setelah tanam.

\section{Fitotoksisitas}

Fitotoksisitas pada rumput teki diamati dengan sistem skor truelove, yakni:
0 = tidak terjadi keracunan (dengan tingkat keracunan 0-5\%, bentuk dan warna daun tidak normal).

$1=$ keracunan ringan (dengan tingkat keracunan 6-10\%, bentuk dan warna daun tidak normal)

2 = keracunan sedang (dengan tingkat keracunan 11-20\%, bentuk dan warna daun tidak normal) $3=$ keracunan berat (dengan tingkat keracunan 21-50 $\%$, bentuk dan warna daun tidak normal)

4 = keracunan sangat berat (dengan tingkat keracunan $>50 \%$, bentuk dan warna daun tidak normal, sehingga daun mengering dan rontok sampai mati).

Penelitian dilakukan dengan menggunakan Rancangan Acak Lengkap (RAL). dengan konsentrasi ekstrak daun cengkeh (Zysygium aromaticum L.) yakni $0 \%$ (kontrol), $5 \%, 10 \%, 20 \%$, dan $50 \%$ dan diulang sebanyak 4 kali. Analisa data dilakukan secara eksperimental. Hasil ihitung dengan analisa statistika ANOVA pada taraf signifikan ( $\alpha$ ) 0.05. Apabila terjadi perbedaan perhitungan yang sangat signifikan, maka dilakukan uji lanjutan dengan uji tukey.

\section{HASIL DAN PEMBAHASAN}

Berdasarkan hasil pada tabel 1 terlihat bahwa tingkatan pemberian konsentrasi ekstrak daun cengkeh berpengaruh terhadap pertumbuhan rerata tinggi rumput teki. Pada grafik 4.1 rerata pertumbuhan tinggi gulma rumput teki kontrol dibandingkan dengan pertumbuhan tinggi rumput teki yang diberikan perlakuan (konsentrasi 5\%, 10\%, 20\%, 50\%) menunjukkan tidak berbeda nyata.

Pada tabel 4.1 dapat dilihat penghambatan tinggi gulma dari aplikasi herbisida berdasarkan penelitian, tingkat penghambatan tinggi gulma rumput teki memang tidak terlihat dengan jelas pada hari ke-15 ke hari 20 pada konsentrasi $0 \%$ (kontrol) 5\%, dan $10 \%$, namun 
pertumbuhan akan terhenti di hari ke 25 dan hari ke 30 terlihat pada konsentrasi $20 \%$ dan $50 \%$.

Pemberian herbisida ekstrak daun cengkeh pada gulma rumput teki dilihat dari tinggi tanamana menunjukkan ada pengaruh terhadap tinggi tanaman rumput teki. Hal ini diduga bahwa senyawa flavonoid, saponin, dan tannin dapat bekerja dengan optimal.

Salah satu senyawa metabolit
sekunder yang berperan sebagai bioherbisida adalah tannin yang termasuk kelompok senyawa fenolik. Penelitian sebelumnya membuktikan bahwa tannin dapat menghambat pertumbuhan, menghilangkan kontrol respirasi pada mitokondria serta menganggu transport ion $\mathrm{Ca}^{+2}$ dan $\mathrm{PO} 4$ 3- sehingga dalam penelitian ini tannin berperan dalam menghambat pertumbuhan tanaman gulma rumput teki. Selain itu senyawa tannin juga menonaktifkan enzim amilase, proteinase, lipase, urease dan menghambat aktivitas hormon giberelin. Selain tannin, senyawa metabolit sekunder yang berperan sebagai bioherbisida adalah flavonoid. Flavonoid memiliki peranan terhadap proses penghambatan pertumbuhan, yakni berperan sebagai penghambat kuat terhadap IAA-oksidase.

Pada konsentrasi tertentu senyawa metabolit sekunder yang digunakan sebagai bioherbisida dapat menghambat dan mengurangi hasil pada proses-proses utama tumbuhan. Hambatan tersebut misalnya terjadi pada pembentukan asam nukleat, protein dan ATP. Jumlah ATP yang berkurang dapat menekan hampir seluruh proses metabolisme sel, sehingga sintesis zat-zat lain yang dibutuhkan oleh tumbuhan pun akan berkurang sehingga flavonoid berperan juga dalam menghambat proses pertumbuhan gulma rumput teki.

Menurut (21) senyawa fenol yang mengandung tannin dan flavonoid mempengaruhi beberapa proses penting seperti penyerapan mineral, keseimbangan air, respirasi, fotosintesis, sintesis protein, klorofil, dan fitohormon. Konsentrasi ekstrak daun cengkeh yang tinggi akan mempengaruhi akar gulma dalam menyerap unsur hara. Kandungan flavonoid dan tannin dalam ekstrak daun cengkeh dapat merusak struktur membran sel sehingga permeabilitasnya akan menurun.

Dalam menghambat proses fotosintesis yang berpengaruh pada tinggi gulma rumput teki dalam penelitian ini ada beberapa faktor bias yang mempengaruhi yaitu intensitas cahaya yang sangat baik bagi proses fotosintesis sehingga tanaman dapat tumbuh menjadi subur, dengan intensitas cahaya yang baik disertai kurangnya nutrisi dalam tanah, ditambah dengan perlakuan ekstrak daun cengkeh yang berpotensi sebagai herbisida alami pada gulma rumput teki membuat unsur hara dalam tanah berkurang sehingga proses fotosintesispun terhambat sehingga gulma tidak tumbuh dengan baik bahkan tanaman menjadi layu dan kering. Pendapat Sarief (1986) yang menyatakan bahwa unsur hara yang cukup tersedia saat pertumbuhan tanaman mengakibatkan fotosintesis berjalan lebih aktif, dengan demikian proses pemanjangan dan diferensiasi sel tumbuhan telah rusak dan lisis, hal ini menyebabkan gulma teki menjadi layu dan kering berpengaruh terhadap fitotoksisitas gulma teki. Dilihat dari hasil uji antara kontrol $(0 \%)$ dengan konsentrasi ekstrak $50 \%$ menunjukkan hasil yang signifikan. 
Tabel 1. Rerata Tinggi Teki (cm) Setelah Diberi Ekstrak Daun Cengkeh Pada Berbagai Konsentrasi.

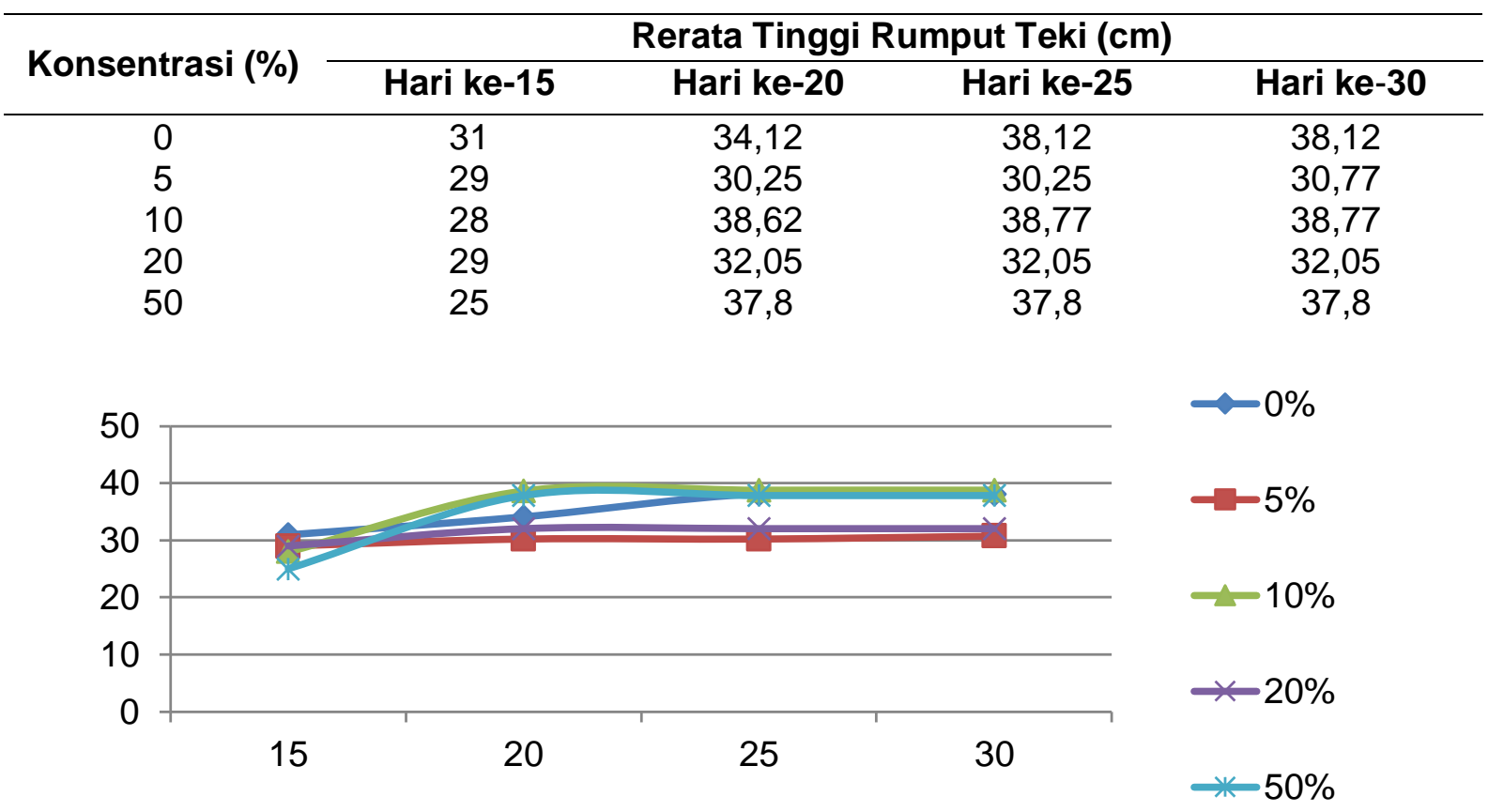

Grafik 1. Grafik Rerata Tinggi Teki Pada Berbagai Konsentrasi

Tabel 4.2. Hasil Uji ANOVA

\begin{tabular}{lccccc}
\hline & Sum of Squares & Df & Mean Square & F & Sig. \\
\hline Between Groups & 18.300 & 4 & 4.575 & .6 .695 & .003 \\
Within Groups & 10.250 & 15 & .683 & & \\
Total & 28.550 & 19 & & & \\
\hline
\end{tabular}

Tabel 3. Fitotoksisitas teki (\%) setelah diberi ekstrak daun Cengkeh pada berbagai Konsentrasi.

\begin{tabular}{cc}
\hline Konsentrasi & Fitotoksisitas \\
\hline $0 \%$ & $0.0000 \mathrm{a}$ \\
$5 \%$ & $2.0000 \mathrm{~b}$ \\
$10 \%$ & $2.2500 \mathrm{~b}$ \\
$20 \%$ & $2.2500 \mathrm{~b}$ \\
$50 \%$ & $2.7500 \mathrm{~b}$ \\
\hline Keterangan: huruf yang sama pada kolom yang sama \\
menunjukkan tidak berbeda nyata berdasarkan uji tukey \\
pada taraf kepercayaan 95\%.
\end{tabular}

Tabel 4. Hasil Uji ANOVA

\begin{tabular}{lccccc}
\hline & Sum of Squares & Df & Mean Square & F & Sig. \\
\hline Between Groups & 13.378 & 4 & 3.345 & 8.853 & .001 \\
Within Groups & 5.667 & 15 & .378 & & \\
Total & 19.045 & 19 & & & \\
\hline
\end{tabular}


Tabel 5. Berat Basah Rumput Teki (\%) Setelah Diberi Ekstrak Daun Cengkeh Pada Berbagai Konsentrasi.

\begin{tabular}{cc}
\hline Konsentrasi & Berat Basah \\
\hline $0 \%$ & $4.3650 \mathrm{~b}$ \\
$5 \%$ & $2.9150 \mathrm{a}$ \\
$10 \%$ & $2.3500 \mathrm{a}$ \\
$20 \%$ & $2.4325 \mathrm{a}$ \\
$50 \%$ & $2.0600 \mathrm{a}$ \\
\hline
\end{tabular}

Berdasarkan tabel di atas, terlihat bahwa terdapat hasil tidak yang berbeda nyata dan jika dilihat antara berbagai konsentrasi (5\%, 10\%, 20\% dan 50\%) yang diaplikasikan hasil yang didapat menunjukkan tidak berbeda nyata. Perbedaan mulai terlihat signifikan pada konsentrasi ekstrak daun cengkeh 50\% dengan memiliki nilai yang tertinggi diantara konsentrasi lainnya. Hal ini diduga karena senyawa metabolit menghasilkan pembelahan sel, seluruh fungsi fisiologi pada Pemberian herbisida ekstrak daun cengkeh pada gulma rumput teki mengguning bahkan kering. Hal inilah yang menyebabkan sel-sel pada gulma teki sudah mati dan kering sehingga tidak dapat seperti flavonoid saponin, dan tannin dapat bekerja lebih optimal pada pemberian konsentrasi 50\%.

Flavonoid adalah salah satu jenis senyawa yang bersifat racun/allelopati, berkaitan dengan hal ini maka diduga flavonoid yang dikeluarkan oleh ekstrak daun cengkeh berpotensi sebagai racun sehingga menganggu proses pertumbuhan gulma rumput teki sehingga berpengaruh terhadap fitotoksisitas gulma rumput teki, penelitian oleh Masriadi (2014) yaitu bahwa senyawa metabolik pada alkaloid, saponin dan tannin dari ekstrak kulit buah jengkol mampu bekerja secara optimal sehingga berpengaruh terhadap fitotoksisitas gulma.

Berdasarkan penelitian ini dapat dilihat bahwa senyawa flavonoid, saponin dan tannin pada ekstrak daun cengkeh berpotensi sebagai bioherbisida yang mampu bekerja pada Hasil uji fitotoksisitas pada tabel 4 menunjukkan bahwa adanya reaksi dari herbisida alami ekstrak daun cengkeh terhadap rumput teki dapat dilihat pada fitotoksisitas (tingkat keracunan) gulma rumput teki. Dari tingkatan fitotoksisitas ini dapat diketahui efektifitas konsentrasi ekstrak daun cengkeh terhadap gulma rumput teki. Dari tabel hasil uji tukey, semakin tinggi ekstrak yang diberikan terdapat perbedaan wilayah grup, yang menandakan bahwa ekstrak daun cengkeh (Zysygium aromaticum L.) memiliki pengaruh terhadap fitotoksisitas, dengan gejala fitotoksisitas yakni pertumbuhan daun yang tidak normal (daun Layu), daun akan terjadi lebih baik yang dapat mendukung pertumbuhan tanaman. Unsur hara yang tersedia dalam tanah pada penelitian ini tidak tercukupi sehingga proses fotosintesis tidak bekerja dengan baik sehingga pertumbuhan gulma juga terhambat.

Pada tabel 5 diketahui adanya perbedaan pada berat basah, hasil menunjukkan konsentrasi $50 \%$ dengan kontrol $(0 \%)$ berbeda nyata dapat dilihat juga dari huruf pada kolom kedua konsentrasi berbeda, sedangkan diantara berbagai konsentrasi (5\%, 10\%, 20\%, 50\%) menunjukkan hasil berat basah rumput teki tidak berbeda nyata dapat dilihat dari huruf pada kolom keempat konsentrasi sama. Perlakuan ekstrak dalam konsentrasi yang rendah yaitu $5 \%, 10 \%$, yang masuk ke dalam jaringan daun telah menghambat aktivitas fisiologis. Namun pada konsentrasi yang lebih tinggi yaitu $20 \%$ dan $50 \%$, penghambatan berat basah menjadi lebih tinggi.

Tabel 6. Hasil Uji ANOVA

\begin{tabular}{lccccc}
\hline & Sum of Squares & Df & Mean Square & F & Sig. \\
\hline Between Groups & 3.955 & 4 & .989 & 4.170 & .018 \\
Within Groups & 3.557 & 15 & .237 & & \\
Total & $\mathbf{7 . 5 1 3}$ & $\mathbf{1 9}$ & & & \\
\hline
\end{tabular}




\section{Tabel 7. Berat Kering Rumput Teki (\%) Setelah Diberi Ekstrak Daun Cengkeh Berbagai Konsentrasi.}

\begin{tabular}{cc}
\hline Konsentrasi & Berat Kering \\
\hline $0 \%$ & $2.4900 \mathrm{~b}$ \\
$5 \%$ & $1.5450 \mathrm{a} \mathrm{b}$ \\
$10 \%$ & $1.5250 \mathrm{a} \mathrm{b}$ \\
$20 \%$ & $1.3875 \mathrm{a}$ \\
$50 \%$ & $1.2150 \mathrm{a}$ \\
\hline Keterangan: huruf yang sama pada kolom yang \\
sama menunjukkan Tidak berbeda nyata \\
berdasarkan uji tukey pada taraf \\
kepercayaan 95\%.
\end{tabular}

Usmana (2012) menyatakan bahwa semakin tinggi konsentrasi ekstrak maka semakin tinggi juga pengaruh penghambatannya terhadap aktivitas fisiologis tanaman. Berdasarkan hal ini dapat dilihat bahwa tingkatan konsentrasi berpengaruh terhadap berat basah gulma rumput teki pada penelitian ini, semakin tinggi ekstrak daun cengkeh yang diaplikasikan pada gulma rumput teki, maka semakin tinggi pengaruh penghambatannya terhadap aktivitas fisiologis tanaman sehingga hasil berat basah yang diperoleh nilainya kecil menunjukkan adanya pengaruh herbisida ekstrak daun cengkeh terhadap jumlah berat basah yang didapat, sebaliknya semakin rendah konsentrasi ekstrak daun cengkeh yang diaplikasikan pada gulma rumput teki, maka semakin rendah pengaruh penghambatannya terhadap aktivitas fisiologis tanaman sehingga hasil berat basah yang diperoleh nilainya besar, dengan nilai yang besar menunjukkan tidak adanya pengaruh herbisida ekstrak daun cengkeh terhadap jumlah berat basah rumput teki.

Senyawa allelopati pada ekstrak daun cengkeh mampu memberikan pengaruh dalam menurunkan berat basah gulma rumput teki pada konsentrasi yang tinggi. Senyawa flavonoid yang terdapat pada ekstrak daun cengkeh dapat menghambat pertumbuhan rumput teki. Penurunan berat basah menunjukkan bahwa proses pertumbuhan mengalami penghambatan. Hal ini dapat terjadi karena terganggunya proses penyerapan air dan terhambatnya proses fotosintesis, yang mengakibatkan daya serap air pada gulma berkurang dan berdampak pada kandungan air pada gulma rumput teki sehingga berpengaruh pada hasil berat basah. Berdasarkan Alfandi dan Dukat (2007) menyatakan bahwa berat basah merupakan total kandungan air dan hasil fotosintesis di dalam tubuh tumbuhan. Hambatan penyerapan air dan proses fotosintesis inilah yang menyebabkan total kandungan air dan hasil fotosintesis berkurang pada tanaman rumput teki.

Berat kering tanaman digunakan secara luas sebagai indikator pertumbuhan, karena menunjukkan besarnya fotosintat yang digunakan untuk melakukan metabolisme tubuh, yang pada akhirnya dapat menentukan tingginya produktivitas tanaman dipandang sebagai manifestasi dari semua proses dan peristiwa yang terjadi dalam pertumbuhan tanaman (Miranti, 2007). Berdasarkan hasil uji Tukey pengamatan berat kering gulma rumput teki dapat diketahui adanya pengaruh perlakuan ekstrak daun cengkeh terhadap berat kering gulma rumput teki. Hal ini diduga karena zat allelopati dari ekstrak daun cengkeh mampu menekan pertumbuhan dan proses fisiologis tanaman.

Berat kering tanaman mencerminkan status hara dan banyaknya unsur hara yang diserap oleh tanaman serta laju fotosintesis. Unsur hara pada tanaman berperan dalam proses metabolisme tanaman untuk memproduksi bahan kering yang tergantung pada laju fotosintesis. Bila laju fotosintesis berbeda, maka jumlah fotosintat yang dihasilkan juga berbeda, demikian juga dengan berat kering tanaman yang merupakan cerminan dari laju pertumbuhan tanaman (10).

Dwiguntoro (2008) menyatakan berat kering suatu tanaman merupakan hasil penumpukan fotosintat yang dalam 
pembentukannya membutuhkan unsur hara, air, CO2 dan cahaya matahari. Kondisi demikian didukung oleh pendapat Moenandir (1988) yang menyatakan bahwa berat kering tanaman mencerminkan akumulasi senyawa-senyawa organik yang merupakan hasil sintesa tanaman dari senyawa anorganik yang berasal dari air dan karbondioksida sehingga memberikan kontribusi terhadap berat kering tanaman.

Pada berat kering gulma rumput teki, yang didapat setelah dioven selama 24 jam dengan suhu $105^{\circ} \mathrm{C}$. Dengan dioven maka seluruh air yang ada pada rumput teki akan hilang sehingga menunjukkan berat organ yang tersisa saja. Dari hasil aplikasi perlakuan (berbagai konsentrasi) herbisida terhadap rumput teki pada tabel 4 didapatkan hasil yang berbeda nyata, antara konsentrasi $50 \%$ dengan kontrol $(0 \%)$, sedangkan konsentrasi $50 \%$ tidak berbeda nyata dengan $20 \%$, demikian pula konsentrasi $10 \%$ tidak berbeda nyata dengan $5 \%$. Hasil analisis ini menunjukkan bahwa herbisida daun cengkeh dengan dosis $50 \%$ efektif untuk mengendalikan gulma rumput teki.

Tingginya berat kering gulma rumpu teki pada penggendalian dengan aplikasi herbisida ekstrak daun cengkeh diduga bahwa senyawa metabolik pada flavonoid, tannin dan saponin yang terkandung dalam ekstrak daun cengkeh tidak mampu bekerja secara optimal pada konsentrasi yang diberikan. Sebaliknya, rendahnya berat kering gulma rumput teki pada aplikasi herbisida ekstrak daun cengkeh memnunjukkan bahwa senyawa flavonoid, tannin dan saponin bekerja secara optimal sehingg mempengaruhi berat kering yang didapat pada penelitian ini.

Dijelaskan oleh Faqihhudin, dkk (2014) bahwa senyawa tannin dalam jumlah yang banyak dapat menonaktifkan enzim amilase, dan dapat menghambat aktivitas hormon giberelin. Pada konsentrasi tertentu senyawa metabolit sekunder yang digunakan sebagai bioherbisida dapat menghambat dan mengurangi hasil proses utama pertumbuhan gulma.

Menurut Johnly A. Rorong, dkk (2001) pertumbuhan tanaman merupakan fungsi dari keefisiensinya dalam memproduksi bahan kering tanaman. Berat kering akan erat hubungannya dengan meningkatnya pertumbuhan dan perkembangan akar dalam menyerap hara untuk pertumbuhan vegetatif tanaman akan terhambat, karena hara yang diserap akar sedikit sehingga mempengaruhi pertumbuhan tanaman.

Hasil penelitian menunjukkan Semakin tinggi konsentrasi ekstrak daun cengkeh terhadap gulma rumput teki, maka berpengaruh pada proses penyerapan unsur hara, air, karbondioksida, matahari oleh rumput teki, sehingga berpengaruh terhadap hasil berat kering rumput teki. Begitu pula semakin sedikitnya konsentrasi maka semakin besar nilai berat kering, karena konsentrasi rendah sehingga belum mampu menghambat proses fisiologis gulma rumput teki.

\section{KESIMPULAN}

Berdasarkan hasil penelitian ini, dapat disimpulkan bahwa Semakin tinggi ekstrak daun cengkeh yang diberikan terhadap gulma rumput teki maka akan semakin berfungsi untuk menghambat gulma rumput teki yang diukur dari tinggi tanaman, fitotoksisitas, berat basah dan berat kering gulma rumput teki. Senyawa metabolit sekunder yang berpotensi sebagai herbisida alami dari ekstrak daun cengkeh yaitu senyawa flavonoid, saponin dan tannin yang bekerja dengan optimal pada konsentrasi $50 \%$, yang dapat dipakai sebagai salah satu alternatif untuk menghambat pertumbuhan gulma rumput teki. Saran untuk penelitian lanjutan adalah perlu adanya penelitian tentang ekstrak daun cengkeh dengan pelarut non-polar supaya dapat diketahui lebih spesifik lagi tentang kinerja ekstrak daun cengkeh, sehingga manfaatnya dapat dikembangkan.

\section{DAFTAR PUSTAKA}

AAK. 1991. Petunjuk bercocok tanam cengkeh. Penerbit Kanisius. Yogyakarta.

Aksi Agraris Kanisius. 1973. Bagaimana menanam cengkeh. Percetakan Kanisius. Yogyakarta.

Alfandi \& Dukat. 2007. Respon pertumbuhan danproduksi tiga kultivar kacang hijau (Vigna radiata L.) terhadap kompetisi dengan gulma 
pada dua jenis tanah vol. 6 , no. 1 , hal. 26-29, diakses 10 februari 2015

Anonym. 2009. BAB II tinjauan pustaka tanaman cengkeh. Universitas sumatera. Sumatera.

Ardianto, Tomi. 2008. Pengaruh Ekstrak Bunga Cengkeh (Syzygium aromaticumL.) terhadap Mortalitas Larva Aedes aegypti L. Fakultas Kedokteran Universitas Sebelas Maret, Skripsi.

Ariestiani. 2000. Kajian Efektivitas Herbisida Glisofat -2,4-D 120/240 AS Glisofat 2,4-D 120/120 AS, dan 2,4-D 865 AS untuk Pengedalian Gulma Pada Tanaman Jagung (Zea maysL.). Fakultas Pertanian. Institut pertanian Bogor.

Arifiyanti. 2010. Uji afrodisiaka minyak atsiri kuncup bunga Cengkeh (Syzygium aromaticum (I.) Merr. \& perry.) Terhadap libido tikus jantan. Skripsi. Universitas Muhammadiyah. Surakarta.

Bustaman. Sjahrul 2011. Potensi pengembangan minyak daun cengkih Sebagai komoditas ekspor Maluku. Balai Besar Pengkajian dan Pengembangan Teknologi Pertanian. Bogor

Djazuli, M., 2002. Alelopati pada tanaman nilam (Pogostemon cablin L.). Jurnal Ilmiah Pertanian. Gakuryoku. 8:163172.

Dwiguntoro. 2008. Sekilas Tentang Gulma. http://dwiguntoro.wordpress.com/2008/ 11/30/ Sekilas Tentang Gulma.html [11 November 2013]

Ellizar dan Maaruf Y. 2009. Penentuan Kandungan Flavonoid dari Ekstrak Metanol Daging Buah Mahkota Dewa (Phaleria macrocarpa scheff boerl). FMIPA, UII. Yogyakarta

Elsari Dwi Harnani. 2010. Perbandingan Kadar eugenol minyak atsiri Bunga cengkeh (syzygium

Aromaticum (I.) Meer. \& perry) Dari Maluku, Sumatera, Sulawesi, dan Jawa dengan metode gc-ms. Skripsi Universitas Muhammadiyah Surakarta. Surakarta.

Fatonah Siti dkk. 2013. Penentuan Waktu Pembukaan Stomata Pada Gulma Melastoma malabathricum L. Di Perkebunan Gambir Kampar, Riau. Universitas Riau. Pekanbaru Riau
Fatonah Siti dkk. 2014. Potensi alelopati ekstrak daun Pueraria javanica Benth terhadap perkecambahan dan pertumbuhan anakan gulma Asystasia gangetica (L.) T. Anderson. Jurnal. Universitas Riau. Pekanbaru Riau.

Faqihhudin dkk. 2014. Penggunaan Herbisida IPA-Glifosat terhadap Pertumbuhan, Hasil dan Residu pada Jagung. Jurnal IImu Pertanian Vol. 17. No.1. Bogor. Jawa Barat.

Haditomo. Indriantoro. 2010. Efek larvasida ekstrak daun cengkeh (syzygium Aromaticum I.) Terhadap aedes aegypti I. Fakultas Kedokteran Universitas Sebelas Maret. Surakarta.

lqbal Saputra. 2011. Pengembangan Sensor Warna Daun Untuk Pemetaan Kepadatan Serangan

Gulma Pada Lahan Terbuka. Jurnal. Institut Pertanian. Bogor.

Faqihhudin dkk.2014. Fisiologi Herbisida (Ilmu Gulma: Buku II). Rajawali. Jakarta.

Johnly A. Rorong dkk. 2012. Analisis fitokimia limbah pertanian Daun cengkih (Eugenia aromatica) sebagai biosensitizer Untuk fotoreduksi besi. Prosiding Seminar Nasional Kimia Unesa. Surabaya

Junaedi Ahmad, dkk. 2006. Ulasan perkembangan terkini kajian alelopati. Institute Pertanian Bogor. Bogor.

Masriadi. 2014. Pengaruh Herbisida Ekstrak Kulit Buah Jengkol Terhadap Pertumbuhan dan Hasil Tanaman Jagung Manis (Zea mays saccharata sturt). Jurnal. Universitas TamanSiswa. Padang.

Moenandir. 1988. Pengantar Ilmu dan Pengendalian Gulma. PT. Raja Grafindo Persada. Jakarta.

Muhamad Djazuli. 2011. Potensi Senyawa Alelopati Sebagai Herbisida Nabati Alternatif Pada Budidaya Lada Organik. Balai Penelitian Tanaman Obat dan Aromatik.Bogor.

Muh Riadi, 2011. Bahan ajar mata kuliah Herbisida dan a plikasinya. Universitas Hasanuddin Makassar

Muljana Wahju. 1999. Cara praktis bercocok tanam cengkeh. Aneka ilmu Semarang.

Novita Hera. 2011. Pengaruh Allelopati beberapa genotipe padi (oryza sativa 
I.) Lokal sumatera barat terhadap perkecambahan dan Pertumbuhan awal gulma echinochloa cruss-galli (I.) Beauv.Universitas Andalas. Padang.

Purba, Edison. 2009. Keanekaragaman herbisida dalam Pengendalian gulma mengatasi populasi Gulma resisten dan toleran herbisida. USU Press. Medan

Rahmi Fitri. 2013. Uji Ekstrak Daun Gulma Babadotan (Ageratum conyzoides I. Terhadap Perkecambahan dan Pertumbuhan Gulma Chromolena odorata I. Univerasitas Riau. Pekanbaru.

Riadi dkk. 2012. Mata Kuliah: Herbisida Dan Aplikasinya. Bahan Ajar. Fakultas Pertanian, Universitas Hassanudin. Makassar

Riskitavani Denada Visita dan Kristanti Indah Purwani. 2013. Studi potensi bioherbisida ekstrak daun Ketapang (terminalia catappa) terhadap gulma Rumput teki (cyperus rotundus) Jurnal Sains Dan Seni Pomits, Jurusan Biologi, Fakultas Matematika dan IImu Pengetahuan Alam, Institut Teknologi Sepuluh Nopember (ITS). Surabaya.

Rorong dkk. 2012. Analisis Fitokimia limbah Pertanian Daun cengkih (Eugenia aromatica) Sebagai biosensitizerUntuk Fotoreduksi Besi.

Prosiding Seminar Nasional Kimia, UNESA, Surabaya

S.A. Lasmini, dan A. Wahid. 2008. "Respon Tiga Gulma Sasaran Terhadap Beberapa Ekstrak Gulma," Jurnal Penelitian Jurusan Hama dan Penyakit Tumbuhan, Universitas Tadulako, Palu.

Sarbino dan E. Syahputra. 2012. Keefektifan parakuat diklorida sebagai herbisida untuk persiapan tanam padi tanpa olah tanah di lahan pasang surut. Sjahril, Rinaldi, 2011. Bahan ajar mata kuliah Herbisid a dan aplikasinya. Universitas Sumatera. Sumatera.

Sukman, Yernelis, dan Yakup. 1991. Gulma dan Teknik Pengendaliannya. PT. Raja Grafindo Persada.

Sunarto dkk. 1999. Aktivitas Antifungal Ekstrak Kasar Daun dan Bunga Cengkeh (Syzigium aromaticum L.) Pada Pertumbuhan Cendawan Perusak Kayu. jurnal Biosmart Volume
1. Surakarta: Jurusan Biologi FMIPA UNS

Suparjo. 2008. Saponin: Peran dan Pengaruhnya bagi Ternak dan Manusia.

Laboratorium Makanan Ternak. Fakultas Peternakan. Universitas Jambi.

Suyanto F. 2009. Efek Larvasida Ekstrak Kulit Buah Manggis (Garcinia mangostana L.) Terhadap Larva Aedes aegypti L. Fakultas Kedokteran Universitas Sebelas Maret, Skripsi

Syam'un Elkawakibi. 2011. Bahan ajar mata kuliah Herbisida dan aplikasinya. Universitas Hasanuddin. Makassar

Tjokrowardojo dan Endjo Djauhariya. 2000. Gulma Dan Pengendaliannya Pada Budidaya Tanaman Nilam. Balai Penelitian Tanaman Obat dan Aromatik. Bogor.

Usmana. 2012. Mustika tani herbisida. http://www.Mustika_tani htm (diunggah tgl 18 juli 2014. 16.45 WIT)

Wahyuni Nunik. 2004. Respon Alternaria solani, Penyebab Penyakit bercak coklat ada Tomat, Terhadap Ekstrak Daun Cengkeh dan Pala secara In-Vitro. Fakultas Pertanian IPB. Bogor.

Wahyuni dkk. 2013. Uji Efektivitas Ekstrak Etanol Daun Cengkeh (Syzygium aromaticum) Sebagai Insektisida Terhadap Nyamuk Aedes aegypti Dengan Metode Elektrik. FKUB.

Yulifrianti elvrina dkk. 2015. Potensi alelopati ekstrak serasah daun mangga (Mangifera indica (I.)) terhadap pertumbuhan gulma rumput grinting (cynodon dactylon (I.)) press. Universitas Tanjungpura. Pontianak. Jurnal Protobiont Vol 4(1). 